\title{
Identification of $\mathbf{M}_{1}$ muscarinic receptors in pulmonary sympathetic nerves in the guinea-pig by use of pirenzepine
}

\author{
${ }^{1}$ Jennifer Maclagan, ${ }^{2}$ Allison D. Fryer \& David Faulkner
}

Department of Pharmacology, Royal Free Hospital Medical School, Rowland Hill Street, London NW3

1 The effect of pirenzepine, a muscarinic antagonist considered to be selective for $M_{1}$ receptors, was studied on bronchoconstriction and bradycardia elicited by preganglionic stimulation of the parasympathetic vagal nerves and by i.v. injections of acetylcholine (ACh) in anaesthetized guineapigs.

2 Pirenzepine was equipotent in the heart and lung as an antagonist of the effects of i.v. ACh at postjunctional muscarinic receptors. Doses of pirenzepine in excess of $1 \mu \mathrm{mol} \mathrm{kg} \mathbf{g}^{-1}$ abolished all muscarinic responses consistent with non-selective blockade of $\mathbf{M}_{3}$ receptors on airway smooth muscle and $M_{2}$ receptors on atrial cells.

3 In the lung, low doses of pirenzepine (1-100 $\left.\mathrm{nmol} \mathrm{kg}^{-1}\right)$ increased vagally-induced bronchoconstriction despite concurrent partial blockade of the postjunctional receptors. This suggests blockade of neuronal muscarinic receptors.

4 Propranolol $\left(1 \mathrm{mg} \mathrm{kg}^{-1}\right)$ increased control bronchoconstrictor responses elicited by ACh and vagal stimulation but did not alter the potency of pirenzepine for postjunctional receptors in heart or lung. However, pirenzepine-induced enhancement of vagally-induced bronchoconstriction was abolished by propranolol, suggesting that pirenzepine may be an antagonist for muscarinic receptors located in the sympathetic nerves innervating airway smooth muscle.

5 These results confirm that bronchoconstrictor stimuli indirectly initiate activation of an opposing sympathetic reflex in the guinea-pig lung. This response is facilitated by muscarinic receptors located in the sympathetic nervous pathway.

6 The high potency of pirenzepine for the neuronal receptors in the sympathetic nerves suggests that these are $M_{1}$ receptors. In contrast, the parasympathetic nerves innervating airway smooth muscle in this species contain $\mathbf{M}_{2}$ receptors which inhibit neurotransmission.

\section{Introduction}

In the lung, the dominant nervous control of airway diameter is exerted by parasympathetic nerves which release acetylcholine $(\mathrm{ACh})$ onto muscarinic receptors on the airway smooth muscle cell. Muscarinic receptors also exist on the post-ganglionic terminals of these cholinergic nerves. These neuronal receptors inhibit transmitter release (Fryer \& Maclagan, 1984; 1987a; Faulkner et al., 1986) and consequently their blockade with muscarinic antagonists increases vagally-induced bronchoconstriction. This may be a potential hazard when muscarinic antagonists such

1 Author for correspondence.

2 Present address: Department of Pharmacology and Toxicology, School of Pharmacy, University of Maryland at Baltimore, Maryland, U.S.A. as ipratropium are used clinically as bronchodilators (Fryer \& Maclagan, 1987b). As muscarinic antagonists affect both prejunctional and postjunctional muscarinic receptors, the degree of blockade of vagally-induced bronchoconstriction produced by these drugs is dependent on the balance between their pre- and postjunctional blocking activity. Thus, it is important to establish whether the neuronal muscarinic receptors belong to the same or to a different receptor subtype from the receptors on the smooth muscle cell.

Muscarinic receptors have been classified into three types on the basis of ligand binding and functional studies by use of selective antagonists. $\mathbf{M}_{1}$ receptors exhibit a high affinity for pirenzepine and are located mainly in neural tissue (Hammer, 1982), 
whereas the muscarinic receptors located on nerves, glands, heart and smooth muscle exhibit a low affinity for pirenzepine. These have been further subdivided by the use of gallamine which is selective for the $\mathbf{M}_{2}$ receptors in the heart (Riker \& Wescoe, 1951) and by dicyclomine and 4-diphenylacetoxy- $\mathrm{N}$ methyl piperidine (4-DAMP) which displays high affinity for the $\mathbf{M}_{3}$ receptors on ileal smooth muscle and glands (de Jonge et al., 1986; Birdsall \& Hulme, 1984). The latter subtype includes the postjunctional receptors on airway smooth muscle (Barlow et al., 1972).

The high potency of gallamine for the pulmonary neuronal receptors in the guinea-pig and cat (Fryer \& Maclagan, 1987a; Blaber et al., 1985) suggests that these receptors may resemble the cardiac $\mathbf{M}_{2}$ muscarinic receptors. However, the effect of pirenzepine has not been tested in the pulmonary autonomic nerves in these species. The present experiments were carried out to examine the effect of pirenzepine in the guinea-pig in an attempt to clarify the subtype of muscarinic receptor found in the pulmonary autonomic nerves.

\section{Methods}

Guinea-pigs (250-300 g, either sex) of the Dunkin Hartley strain were anaesthetized with urethane $\left(1.5 \mathrm{~g} \mathrm{~kg}^{-1}\right.$, i.p.). The right carotid artery was cannulated for the measurement of blood pressure and heart rate was derived electronically from the blood pressure signal. A cannula was placed in the left jugular vein for the injection of drugs. Both vagi were cut and the distal ends placed on shielded platinum electrodes immersed in a pool of liquid paraffin. Each animal's body temperature was maintained at $37^{\circ} \mathrm{C}$ by use of a CFP 8185 homeothermic blanket control.

The anaesthetized animals were paralysed with suxamethonium chloride $\left(100 \mu \mathrm{g} \mathrm{kg}^{-1}\right)$ injected every $10 \mathrm{~min}$ and respired with positive pressure, constant volume ventilation from a Harvard Rodent respirator. Airflow $(\dot{\mathrm{V}})$ and tidal volume $(\mathrm{Vt})$ were recorded as described by Maclagan \& Ney (1979). Pulmonary inflation pressure (Ppi) was measured with a Statham pressure transducer (PM5E): one port of the transducer was connected to a side arm of the tracheal cannula and the other port was open to the atmosphere. All signals were displayed on a Gould Recorder and arterial blood samples were taken at regular intervals and analysed for $\mathrm{O}_{2}$ and $\mathrm{CO}_{2}$ tension and pH with a Corning 166 microsample blood gas analyser. The tracheal cannula used had a resistance of $40-60 \mathrm{cmH}_{2} 0.1^{-1} \mathrm{~s}^{-1}$, so a positive pressure of approximately $80-100 \mathrm{mmH}_{2} \mathrm{O}$ was needed at each stroke of the pump for adequate ventilation of the animal.

Bronchoconstriction elicited by i.v. ACh or by vagal nerve stimulation was recorded as described by Fryer \& Maclagan (1984) as an increase in Ppi over the basal insufflation pressure change produced by the pump. The sensitivity of the method was increased by using a computerized device to subtract the basal tracheal insufflation pressure. The 'subtractor' was re-set before each bronchoconstrictor stimulus and the increase in Ppi which occurred during the ensuing bronchoconstriction was recorded on a second channel of the Gould recorder at higher amplification. The changes in pressure in the trachea recorded in this way probably reflect changes in both resistance and compliance components of the lungs.

Bronchoconstriction and bradycardia were elicited either by intravenous injection of $\mathrm{ACh}$, or by preganglionic stimulation of both cervical vagus nerves $(30 \mathrm{~Hz}, 0.2 \mathrm{~ms}, 5 \mathrm{~s} 10-20 \mathrm{~V})$. Pirenzepine was injected i.v. in cumulative doses. Following each dose of pirenzepine, the responses to nerve stimulation and $\mathrm{ACh}$ were measured alternately at $2 \mathrm{~min}$ intervals.

All results were expressed as the ratio of the response to agonist or nerve stimulation after the antagonist (B2) divided by the response before administration of the antagonist (B1).

The experiments were repeated in a second group of animals which received propranolol $\left(1 \mathrm{mg} \mathrm{kg}^{-1}\right.$, i.v.) $30 \mathrm{~min}$ before administration of cumulative doses of pirenzepine.

\section{Statistical procedures}

Results are expressed as mean values \pm s.e.mean from $n$ experiments. Differences between means were tested for significance by use of the unpaired $t$ test and values of $P<0.05$ were taken as significant.

\section{Drugs}

Urethane and suxamethonium chloride (Sigma), acetylcholine bromide (BDH), pirenzepine hydrochloride (Boehringer) and propranolol hydrochloride (ICI) were used. All drugs were dissolved in $0.9 \%$ $\mathrm{NaCl}$ solution (saline).

\section{Results}

The effect of pirenzepine was studied on bronchoconstriction and bradycardia elicited either by intra- 
venous injection of $\mathrm{ACh}$, or by stimulation of both cervical vagus nerves. The responses induced by i.v. $\mathrm{ACh}$ were used as a measure of postjunctional muscarinic receptor activation in the lungs and heart.

Dose-response curves for bronchoconstriction induced by vagal nerve stimulation were obtained at the start of each experiment and stimulus parameters were then selected for the rest of the experiment (control response, see Figure 1) which produced approximately $50 \%$ of the maximal response. A dose of ACh was then selected to cause an increase in Ppi comparable to that produced by the control stimulus to the vagus nerve. In separate experiments saline injections were used instead of pirenzepine and the results showed that repeated alternating application of ACh or vagal nerve stimulation elicited reproducible bronchoconstrictor responses for several hours (Fryer \& Maclagan, 1987a).

Administration of pirenzepine in cumulative doses reduced the bronchoconstriction induced by i.v. $\mathrm{ACh}$, as shown by a decrease in the B2/B1 ratio, due to blockade of the muscarinic receptors located postjunctionally on the heart and on airway smooth muscle (Figure 1). In each experiment, the dose of pirenzepine that produced $50 \%$ inhibition of the
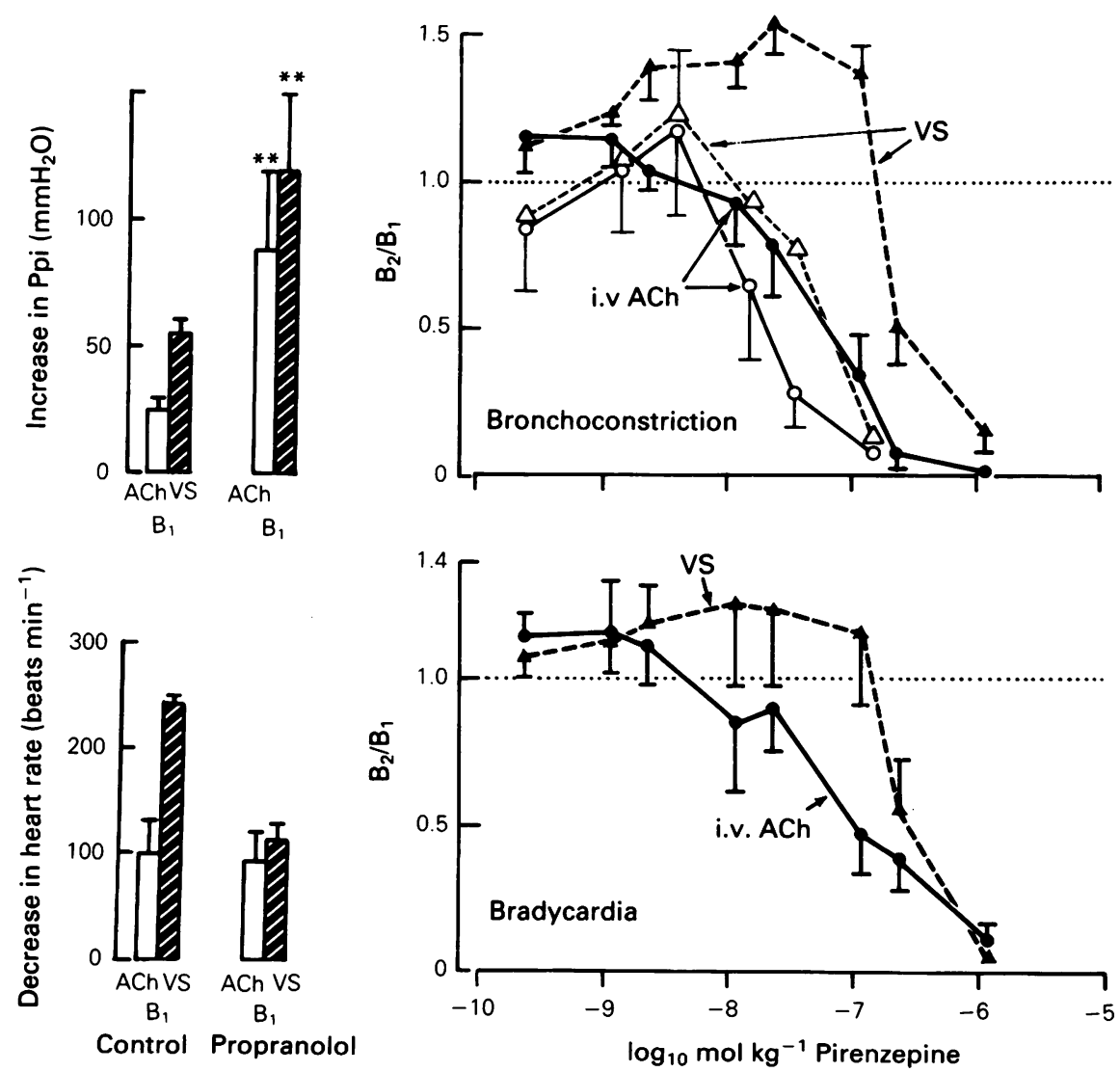

Figure 1 Summary of results showing the effect of pirenzepine on bronchoconstriction (measured as an increase in pulmonary inflation pressure (Ppi)) and bradycardia induced by vagal nerve stimulation (VS; $30 \mathrm{~Hz}, 0.2 \mathrm{~ms}, 3 \mathrm{~s}$, $10-20 \mathrm{~V} ; \Delta)$ or by intravenous acetylcholine $\left(\mathrm{ACh} 1 \mu \mathrm{g} \mathrm{kg}^{-1} ; O\right)$. The control responses (B1) to VS (hatched columns) and $\mathrm{ACh}$ (open columns) before pirenzepine are shown on the left. Results are expressed in the graphs as the ratio $\mathrm{B} 2 / \mathrm{B} 1$ where $\mathrm{B} 2$ is the response after pirenzepine.

A second group of guinea-pigs was pretreated with propranolol (1 $\mathrm{mg} \mathrm{kg}^{-1}$, open symbols), which abolished the pirenzepine-induced potentiation of vagally-induced bronchoconstriction. The effect of pirenzepine in the heart was not significantly altered by propranolol (not shown but see Table 1). Note that the control bronchoconstrictor responses were potentiated by propranolol. (Mean results with s.e.mean shown by vertical bars; $n=6$ ). 
Table 1 Antagonist activity of pirenzepine in lung and heart

\begin{tabular}{lcc}
\hline Response & \multicolumn{2}{c}{$\begin{array}{c}\text { Pirenzepine ED } \\
\text { (nmol kg }\end{array}$} \\
& \multicolumn{1}{c}{ ) }
\end{tabular}

Dose of pirenzepine causing $50 \%$ inhibition of responses induced by acetylcholine (ACh) and by vagal stimulation in heart and lung $\left(E_{50}\right.$, $\mathrm{nmol} \mathrm{kg}^{-1}$ ). Values were calculated for each individual guinea-pig and the table shows the mean ED $_{50} \pm$ s.e.mean $(n=6)$ for a control group of animals compared with a second group that received propranolol $\left(1 \mathrm{mg} \mathrm{kg}^{-1}\right)$ at the start of the experiment. Baseline values for the two groups, in absolute units, are given in Figure 1.

** Different from control: $P<0.002$.

responses was calculated $\left(E D_{50}\right)$ and the mean $\mathrm{ED}_{50}$ values for 5 experiments are summarized in Table 1 . These results show that pirenzepine was approximately equipotent as an antagonist for the postjunctional muscarinic receptors located on airway smooth muscle and on the atrial cell.

\section{Effect of pirenzepine on vagally-induced bronchoconstriction and bradycardia}

In the same experiments, the effects of pirenzepine were tested on vagally-mediated responses (Figure 1). In the heart, vagally-induced bradycardia was progressively inhibited by increasing doses of pirenzepine in parallel with the inhibition of $\mathrm{ACh}$-induced bradycardia. This is consistent with blockade of the postjunctional muscarinic receptors on the atrial cell.

However, in the lung vagally-induced bronchoconstriction was increased by low doses of pirenzepine, occurring at doses below $100 \mathrm{nmol} \mathrm{kg}^{-1}$, when the postjunctional receptors were either unaffected or partially blocked (Figure 1). As the dose of pirenzepine increased above $100 \mathrm{nmol} \mathrm{kg}^{-1}$, vagallyinduced bronchoconstriction gradually decreased and was finally abolished concurrently with inhibition of the response to $\mathrm{ACh}$ due to blockade of the postjunctional receptors.

One consequence of this enhancement of vagallymediated bronchoconstriction by pirenzepine was that the $\mathrm{ED}_{50}$ for pirenzepine as an antagonist of vagally-induced bronchoconstriction was higher than that needed to inhibit $\mathrm{ACh}$-induced bronchoconstriction (Table 1).

In a second group of animals, the effect of pirenzepine was studied after pretreatment with propranolol (1 $\mathrm{mg} \mathrm{kg}^{-1}$, i.v.). The control bronchoconstrictor responses elicited by both $\mathrm{ACh}$ and vagal stimulation were increased by propranolol (see control responses in Figure 1). Despite this change, the potency of pirenzepine for the postjunctional receptors in the lung was unaltered by $\beta$-adrenoceptor blockade. There was no significant change in the potency of pirenzepine for vagally-mediated or $\mathrm{ACh}$ induced responses in the heart (Table 1). However, pirenzepine no longer caused an increase in vagallyinduced bronchoconstriction after propranolol pretreatment (Figure 1, Table 1).

\section{Discussion}

The results presented in this paper based on functional tests in the guinea-pig demonstrate that postjunctional muscarinic receptors in the heart and lung have similar affinity for pirenzepine in vivo. This is in agreement with previous work both in vivo and in vitro showing that pirenzepine can be used as a selective antagonist for $M_{1}$ receptors but does not distinguish between $M_{2}$ and $M_{3}$ muscarinic receptors (see Eglen \& Whiting, 1986).

It is known from previous work that muscarinic receptors also exist on the parasympathetic nerve terminals innervating airway smooth muscle in several species including guinea-pig (Fryer \& Maclagan, 1984), cat (Blaber et al., 1985), dog (Ito \& Yoshitomi, 1988) and man (Minette \& Barnes, 1987). These muscarinic autoreceptors exert an inhibitory effect on pulmonary parasympathetic neurotransmission so that blockade with an antagonist potentiates vagally-mediated bronchoconstriction. Thus, as the effect of muscarinic antagonists on vagally-induced bronchoconstriction depends on the balance between their prejunctional and postjunctional antagonist action, the potency for the prejunctional receptors will be underestimated (Fryer \& Maclagan, 1987a).

Gallamine is a potent antagonist for the pulmonary neuronal receptors in all of the above species suggesting that these receptors probably resemble the cardiac muscarinic receptors and differ from the receptors on airway smooth muscle where the potency of gallamine is low. Thus the neuronal receptors in pulmonary nerves appear to be similar to the muscarinic receptors mediating prejunctional inhibition in other autonomic nerves which are 
known to be of the cardiac $M_{2}$ subtype (Ashe \& Yarosh, 1984; Newberry et al., 1985; Egan \& North, 1986).

In view of these findings, it was surprising that the selective $M_{1}$ antagonist, pirenzepine, increased vagally-induced bronchoconstriction at low doses as described in this paper. In order to block the postjunctional $\mathbf{M}_{3}$ muscarinic receptors on airway smooth muscle and the $M_{2}$ receptors on the atrial cell, the dose of pirenzepine had to be increased ten fold. This suggests that the pirenzepine-induced enhancement of bronchoconstriction due to vagal stimulation may be due to blockade of $M_{1}$ receptors, with a high affinity for pirenzepine, located in the pulmonary autonomic nerves.

The results with pirenzepine differed in one important respect from those previously obtained with gallamine in this species. Propranolol abolished the pirenzepine-induced enhancement of vagal stimulation, whereas such an effect of gallamine was unaltered by $\beta$-adrenoceptor blockade (Fryer \& Maclagan, 1984). This suggests that these pirenzepine-sensitive $M_{1}$ receptors must be located in the sympathetic nervous pathway (see Figure 2), in contrast to the gallamine-sensitive receptors, which are located on the parasympathetic nerve terminals innervating airway smooth muscle (Faulkner et al., 1986).

Stimulation of pulmonary sympathetic nerves causes bronchodilatation via activation of $\beta$ adrenoceptors on airway smooth muscle; there is also evidence that the sympathetic nerves may inhibit parasympathetic neurotransmission at the ganglia (Partanen et al., 1982) and at the prejunctional cholinergic nerve terminals (Vermeire \& Vanhoutte, 1979). Blockade by pirenzepine of $\mathbf{M}_{1}$ receptors which facilitate neurotransmission in the sympathetic nerves would, therefore, reduce noradrenaline release and indirectly increase the effect of parasympathetic nerve stimulation. These $M_{1}$ receptors could be located either on the final terminals of the sympathetic postganglionic neurones or at the ganglia (see Figure 2). In the latter case, they would be comparable with the $M_{1}$ receptors with a facilitatory role that have been described in sympathetic ganglia in several species (Brown et al., 1980; Mutschler \& Lambrecht, 1984; Ashe \& Yarosh, 1984; Newberry et al., 1985). Activation of these receptors probably closes a specific subset of voltagesensitive $\mathrm{K}^{+}$channels (Brown, 1983). It is interesting that this facilitatory mechanism is absent from parasympathetic ganglia (Brown, 1988).

These results also imply that the sympathetic nerves must have been activated whenever bronchoconstriction was elicited by vagal nerve stimulation or by injected ACh. This conclusion is supported by the finding described in this paper that the control

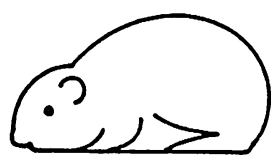

Parasympathetic nerves

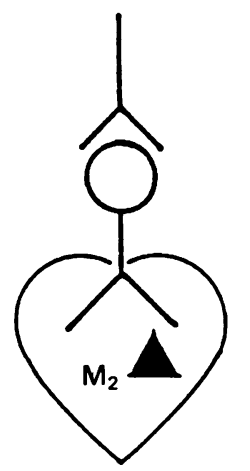

Sympathetic nerves

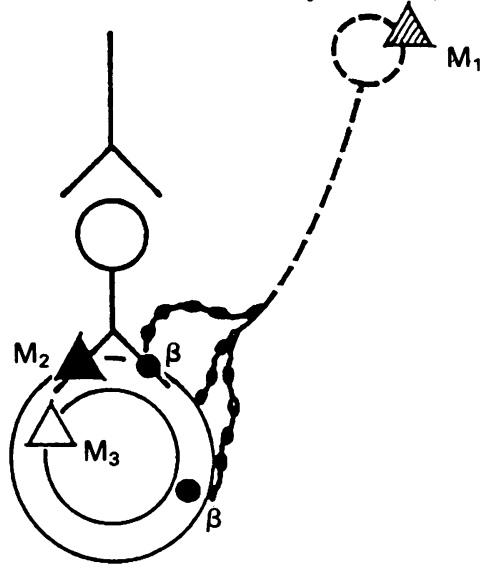

Figure 2 Proposed location of muscarinic receptors in autonomic nerves innervating heart and lung. $\mathbf{M}_{1}$-pirenzepine-sensitive facilitory receptors: $\mathbf{M}_{2}$-gallamine-sensitive inhibitory receptors: $\mathbf{M}_{3}$ receptors on airway smooth muscle: $\beta$-adrenoceptors on cholinergic nerves and airway smooth muscle. The ganglionic nicotinic receptors have been omitted.

bronchoconstrictor responses to $\mathrm{ACh}$ and to vagal nerve stimulation were increased after propranolol pretreatment due to removal of the bronchodilator influence of the sympathetic nervous system.

Evidence for reflex activation of the pulmonary sympathetic nerves has been reported previously in the guinea-pig by McCulloch et al. (1967) using histamine as the bronchoconstrictor agent. It is not 
clear whether this reflex is triggered by afferent nerve stimulation or by anoxia per se but the afferent limb of the reflex pathway must lie outside the vagal nerves as, in the experiments described in the present paper and in those of McCulloch et al. (1967), the animals were vagotomized.

The distribution of $\mathbf{M}_{1}$ muscarinic receptors in the autonomic nerves supplying the lung appears to vary between different species. Although it was not possible to demonstrate $M_{1}$ receptors in the parasympathetic nerves innervating airway smooth muscle in the guinea-pig, such receptors have been demonstrated in these nerves in the dog (Ito \& Yoshitomi, 1988). It has been suggested that $M_{1}$ receptors exist in the rabbit pulmonary parasympathetic nerves because pirenzepine was apparently a potent antagonist of vagally-induced bronchoconstriction in this species (Bloom et al., 1987). However, the interpretation of the results in the rabbit is complicated by the fact that the influence of the sympathetic nervous system and blockade of postjunctional receptors were not directly excluded in the latter experiments. $\mathbf{M}_{2}$ receptors, on the other hand, appear to exist in pulmonary parasympathetic nerves in many species. They have been demonstrated in parasympathetic nerves in the guinea-pig (Fryer \& Maclagan, 1984), cat (Blaber et al., 1985), dog (Ito \& Yoshitomi, 1988) and human (Minette \& Barnes, 1987). In each of these examples, the receptors exerted an inhibitory control on cholinergic neurotransmission to airway smooth muscle. This autoreceptor mechanism appears to be lacking in the rabbit (Maclagan \& Faulkner, 1989) and in asthmatic patients (Minette et al., 1988).

Figure 2 shows the mechanisms that underlie the results presented in this paper and in previous work from this laboratory showing that $\mathbf{M}_{1}$ muscarinic

\section{References}

ASHE, J.H. \& YAROSH, C.A. (1984). Differential and selective antagonism of the slow-inhibitory postsynaptic potential and slow excitatory postsynaptic potential by gallamine and pirenzepine in the superior cervical ganglion of the rabbit. Neuropharmacology, 23, 1321-1329.

BARLOW, R.B., FRANKS, F.M. \& PEARSON, J.D.M. (1972). A comparison of the affinities of antagonists for acetylcholine receptors in the ileum, bronchial muscle and iris of the guinea-pig. Br. J. Pharmacol., 46, 300-314.

BIRDSALL, N.J.M. \& HULME, E.C. (1984). Muscarinic receptor subclasses. Trends Pharmacol. Sci., 4, 459-463.

BLABER, L.C., FRYER, A.D. \& MACLAGAN, J. (1985). Neuronal muscarinic receptors attenuate vagally-induced contraction of feline bronchial smooth muscle. $\mathrm{Br}$. $J$. Pharmacol., 86, 723-728.

BLOOM, J.W., YAMAMURA, H.I., BAUMGARTNER, C. \& HALONEN, M. (1987). A muscarinic receptor with a high receptors with a facilitatory function exist in the sympathetic nervous pathway in the guinea-pig lung (this paper) and $\mathbf{M}_{2}$ receptors exist in the parasympathetic nerves in this species (Fryer \& Maclagan, 1984). These $\mathbf{M}_{2}$ receptors resemble the cardiac $\mathbf{M}_{2}$ receptors as shown by the antagonist potency of gallamine (Fryer \& Maclagan, 1987a).

As the sympathetic nervous system exerts an inhibitory effect on parasympathetic neurotransmission in the guinea-pig, any procedure that reduces the influence of the sympathetic nerves would be expected to increase the bronchoconstrictor effect of the cholinergic pathway. This explains why both $M_{1}$ antagonists and $\beta$ adrenoceptor blocking drugs (Maclagan \& Ney, 1979) potentiate vagally-induced bronchoconstriction in this species.

In man, the existence of $M_{1}$ receptors in the sympathetic pathway to the lung has not been investigated but it is known that prejunctional $\beta$-adrenoceptors exist in human pulmonary parasympathetic nerves (Rhoden et al., 1988). If the sympathetic nervous system exerts an inhibitory effect on parasympathetic neurotransmission in man, comparable to that shown in the guinea-pig, this could provide an explanation for the bronchospasm provoked by $\beta$-adrenoceptor blocking drugs in asthmatic patients, but not in normal subjects. Blockade of the prejunctional $\beta$-adrenoceptors should cause an increase in $\mathrm{ACh}$ release. In normal individuals this would activate the muscarinic autoreceptors to limit transmitter output to the airway smooth muscle. In asthmatic patients however, where there is an apparent absence of prejunctional $\mathbf{M}_{2}$ receptors, $\beta$ adrenoceptor blockade might result in an increase in ACh release which would exacerbate bronchoconstriction. affinity for pirenzepine mediates vagally-induced bronchoconstriction. Eur. J. Pharmacol., 133, 21-27.

BROWN, D.A. (1983). Slow cholinergic excitation - a mechanism for increasing neuronal excitability. Trends Neurosci., 6, 302-307.

BROWN, D.A. (1988), M-currents: an update. Trends Neurosci., 11, 294-299.

BROWN, D.A., FATHERAZI, S., GARTHWAITE, J. \& WHITE, R.D. (1980). Muscarinic receptors in rat sympathetic ganglia. Br. J. Pharmacol., 70, 577-592.

de JONGE, A., DOODS, H. N., RIESBOS, J. \& van ZWEITEN, P.A. (1986). Heterogeneity of muscarinic binding sites in rat brain, submandibular gland and atrium. Br.J. Pharmacol., 89, 551P.

EGAN, T.M. \& NORTH, R.A. (1986). Acetylcholine hyperpolarises central neurones by acting on an $\mathbf{M}_{2}$ muscarinic receptor. Nature, 319, 405-407. 
EGLEN, R. M. \& WHITING, R. L. (1986). Muscarinic receptor subtypes: A critique of the current classification and a proposal for a working nomenclature, J. Auton. Pharmacol., 5, 323-346.

FAULKNER, D., FRYER, A.D. \& MACLAGAN, J. (1986). Postganglionic muscarinic inhibitory receptors in pulmonary parasympathetic nerves in the guinea-pig. $\mathrm{Br} . J$. Pharmacol., 88, 181-187.

FRYER, A.D. \& MACLAGAN, J. (1984). Muscarinic inhibitory receptors in pulmonary parasympathetic nerves in the guinea-pig. Br. J. Pharmacol., 83, 973-978.

FRYER, A.D. \& MACLAGAN, J. (1987a). Pancuronium and gallamine are antagonists for pre- and post-junctional muscarinic receptors in the guinea-pig lung. NaunynSchmiedebergs Arch Pharmacol., 335, 367-371.

FRYER, A.D. \& MACLAGAN, J. (1987b). Ipratropium bromide potentiates bronchoconstriction induced by vagal nerve stimulation in the guinea-pig Eur. J. Pharmacol., 139, 187-191.

HAMMER, R. (1982). Subclasses of muscarinic receptors. Further experimental evidence, Scand. J. Gastroenterol., 17 (Suppl. 72), 59-65.

ITO, Y. \& YOSHITOMI, T. (1988). Autoregulation of acetylcholine release from vagus nerve terminals through activation of muscarinic receptors in the dog trachea. $B r . J$. Pharmacol., 93, 636-646.

MACLAGAN, J. \& FAULKNER, D. (1989). Effect of pirenzepine and gallamine on cardiac and pulmonary muscarinic receptors in the rabbit. Br. J. Pharmacol., 97, 506-512.

MACLAGAN, J. \& NEY, U.M. (1979). Investigation of the mechanism of propranolol-induced bronchoconstriction. Br. J. Pharmacol., 66, 409-418.
McCUlloCh, M.W., PROCTOR, C. \& RAND, M.J. (1967). Evidence for an adrenergic homeostatic bronchodilator reflex mechanism. Eur. J. Pharmacol., 2, 151-157.

MINETTE, P.H. \& BARNES, P.J. (1987). Inhibitory receptors on cholinergic nerves to human and guinea-pig airways. Am. Rev. Resp. Dis., 135, A96.

MINETTE, P.H., LAMMERS, J.W. \& BARNES, P.J. (1988). Prejunctional inhibitory muscarinic receptors on cholinergic nerves in human and guinea-pig airways. Am. Rev. Resp. Dis., 137, 239.

MUTSCHLER, E. \& LAMBRECHT, G. (1984). Selective muscarinic agonists and antagonists in functional tests. Trends Pharmacol. Sci., 5, Suppl. 39-44.

NEWBERRY, N.R., PRIESTLEY, T. \& WOODRUFF, G. N. (1985). Pharmacological distinction between two muscarinic responses on the isolated cervical ganglion of the rat. Eur. J. Pharmacol., 116, 191-192.

PARTANEN, M., LAITINEN, A., HERVONEA, A., TOIVANEN, M. \& LAITINEN, L.A. (1982). Catecholamines and acetylcholinesterase containing nerves in human lower respiratory tract. Histochemistry, 76, 175-188.

RHODEN, K.J., MELDRUM, L.A. \& BARNES, P.J. (1988). Lubrication of cholinergic neurotransmission in human airways by $\beta_{2}$-adrenoceptors. J. Appl. Physiol., 65, 700708.

RIKER, W.F. \& WESCOE, W.C. (1951). The pharmacology of flaxedil with observations on certain analogues. Ann. New York Acad. Sci., 54, 373-392.

VERMEIRE, P.A. \& VANHOUTTE, P.M. (1979). Inhibitory effects of catecholamines in isolated canine bronchial smooth muscle. J. Appl. Physiol., 46, 787-791.

(Received July 29, 1988

Revised December 2, 1988 Accepted January 23, 1989) 